KS. WALDEMAR W. ŻUREK* - LUBLIN

\title{
WIZYTACJA KOŚCIOLA PARAFIALNEGO W DYWINIE Z 1844 ROKU
}

Miasto kresowe Dywin w powiecie kobryńskim, oddalone o 38 kilometrów od miasta powiatowego Kobryń, położone było wśród bagien na dość żyznych gruntach. Miało katolicki kościół parafialny, dwie cerkwie prawosławne i bożnicę. Po 1921 roku Dywin utracił prawa miejskie i liczył 2299 mieszkańców. Od 1991 znajduje się w granicach Białorusi (białoruskie Дзівін) jako duża wieś na Polesiu Brzeskim, w obwodzie brzeskim, rejonie kobryńskim, w pobliżu z granicą Ukrainy.

Kościół pw. Wniebowzięcia Najświętszej Maryi Panny z fundacji królów Jana Kazimierza i Michała Wiśniowieckiego, pochodzi z 1660 roku. Początki parafii posiadającej patronat królewski ${ }^{1}$ sięgają ok. 1700 roku. Parafia dywińska należała do dekanatu Szereszów, w diecezji łuckiej. Ks. Jan Antoni Wojewódzki, pracujący w parafii dywińskiej od 1722 roku jako komendarz, a od 1728 roku proboszcz, wybudował w Dywinie drewniany kościół. Jego poświęcenia dokonał w 1743 roku biskup łucki Franciszek Antoni Kobielski². W 1798 roku parafia przeszła do

\footnotetext{
* Ks. Waldemar W. Żurek - dr hab. historii Kościoła, dyrektor Ośrodka Archiwów Bibliotek i Muzeów Kościelnych KUL.

${ }^{1} \mathrm{~W}$ ustawodawstwie kościelnym patronat stanowił prawa nadawane przez Kościół na rzecz beneficjum i kościoła. Należało do nich głównie prawo prezentowania biskupowi kandydata do objęcia beneficjum kościelnego, czyli udzielanie kandydatowi prezenty na beneficjum. Patronem mogła być osoba duchowna, świecka, a nawet osoba innego, niekatolickiego wyznania. Były także patronaty mieszane: duchowny - świecki lub osoby niekatolickiego wyznania. Występowały patronaty personalne, przynależne danej osobie lub realne, przypisane do posiadanego majątku nieruchomego. Kościoły w Rzeczypospolitej posiadały patronaty: szlachecki - szlachty i magnatów, duchowny - należący do osób i instytucji kościelnych, królewski, książęcy, mieszczański, Uniwersytetu Jagiellońskiego i cesarski (na Śląsku). Por. L. Królik, Organizacja diecezji łuckiej i brzeskiej od XVI do XVIII wieku, Lublin 1983, s. 287; L. Litak, Kościót taciński w Rzeczypospolitej około 1772 roku, Lublin 1996, s. 78-79.

${ }^{2}$ Bp Kobielski Franciszek Antoni (1679-1755), herbu Poraj. Jego rodzina wywodziła się z miejscowości Kobiele koło Radomska. Święcenia kapłańskie otrzymał w 1706 roku w katedrze wawelskiej. W 1708 roku otrzymał kanonię krakowską, w 1709 łowicką, w 1714 gnieźnieńską, w 1717 został prepozytem kapituły krakowskiej. W 1725 roku mianowany sufraganem kujawsko-pomor-
} 
diecezji wileńskiej, w której pozostała do 1925 roku. W 1866 roku parafia dywińska została skasowana, a świątynię przejęli prawosławni. Odrodzenie parafii katolickiej nastapiło w 1917 roku. Ostatnim proboszczem w Dywinie jako parafii w diecezji wileńskiej był w latach 1924-1925 ks. Fabian Poczobut. Należało do niej wówczas 900 wiernych $^{3}$. Od 1925 roku parafia Dywin należała do nowo erygowanej diecezji pińskiej.

\section{Opis fizyczny dokumentu rękopiśmiennego: „Wizyta Kościoła Dywinskiego za rok 1844"}

Rękopis spisany na papierze wytworzonym techniką tzw. laną, z widocznym w dolnej części grzbietu znakiem wodnym w formie liczby tj. 1814, zapewne daty produkcji papieru. Dokument o wymiarach: $355 \times 228 \mathrm{~mm}$, w formie jednej składki - 7 kart złożonych na pół, co daje 28 niepaginowanych stron, zszyty podwójną bawełnianą nicią widoczną na zewnątrz, zapisany czarnym atramentem w języku polskim, wyraźnym, ładnym duktem, pochylonym w prawo. Oprócz ostatnich pięciu linijek całość pisana jest jedną ręką. Na pierwszej stronie tytuł wypisano większymi literami, tak jak i nagłówek na stronie trzeciej, rozpoczynającej tekst. Tekst od 3 do 23 strony wpisany jest pomiędzy pionowe linie, które tworzą marginesy po lewej i prawej stronie (marginesy wahają się między 28-30 $\mathrm{mm}$ ). Od strony 4 do 13 i na stronach 19 i 20 znajdują się tabelki, 5 ostatnich stron nie jest zapisane.

Na pierwszej stronie, która spełnia także funkcję oprawy, w górnym lewym rogu wyciśnięta jest owalna sucha pieczęć o wymiarach $23 \times 18 \mathrm{~mm}$. W środkowej części pieczęci, w prążkowanym owalnym polu widoczne są dwie litery $K T$ zwieńczone koroną, otoczone ozdobnym obramowaniem w formie spłaszczonej spirali. Pieczęć odciśnięta jest tak mocno, że przebija aż do 19 strony. Wszystkie karty, na których znajduje się tekst, złączone są plecionym dwukolorowym sznurkiem, którego końce zatopione zostały w czerwonej lakowej pieczęci. Na pierwszej stronie $\mathrm{w}$ dolnej połowie dokumentu naklejone są dwie białe kartki z papieru maszynowego (jedna na drugiej). Na wierzchniej $(147 \times 54 \mathrm{~mm})$ wypisana jest czcionką maszynową informacja dotycząca treści dokumentu, miejsca przechowywania oraz sygnatura. Spodnia kartka jest nieco większa i w górnym prawym rogu zerwana. Górna część grzbietu, poniżej odcisku pieczęci oklejona jest białą karteczką $(112 \times 38 \mathrm{~mm})$ obejmującą grzbiet od góry i dołu z maszynowym pismem podającym powyżej przytoczoną informację.

Dokument umieszczony jest $\mathrm{w}$ tekturowej teczce.

Stan zachowania dokumentu na dzień 14 grudnia 2012 roku.

skim, w 1736 prekonizowany na biskupstwo w Kamieńcu Podolskim, w 1739 roku przeniesiony przez króla Augusta III na biskupstwo do Łucka. Na Wołyniu i Podolu pasterzował ponad 15 lat. Zmarł w Janowie Podlaskim i tam pochowany. Por. S. Tylus, Kobielski Franciszek Antoni, EK, t. 9 Lublin 2002, k. 220-221; R. Prokop, Biskupi kamienieccy od średniowiecza do współczesności. Szkice biograficzne, Biały Dunajec - Ostróg, s. 278-285.

${ }^{3}$ Spis kościołów i duchowieństwa diecezji pińskiej w R. P. 1939, Pińsk 1939, s. 99.

${ }^{4}$ Archiwum Diecezjalne w Drohiczynie, Zespół: Archiwum Parafii Dywin, Sygn. III/I/2 - Inwentarz Kościoła Par. Dywin 1844. 
Dokument jest bardzo zabrudzony, pognieciony, szczególnie pierwsza i ostatnia strona, naroża są pozawijane, dolny brzeg jest mocno uszkodzony, wszystkie karty są poszarpane i rozpulchnione, wżery spowodowane przez mikroorganizmy sięgają około $40 \mathrm{~mm}$ w górę kart. Powodem tak poważnego uszkodzenia było zalanie dokumentu, którego brunatne ślady widoczne są w dolnej partii całego dokumentu. Na wszystkich stronach widać brązowe zaplamienia, szczególnie na brzegach kart. Wierzchnia i spodnia karta na brzegach pobrudzone są odchodami owadów. Od strony 21 do ostatniej w środkowej części dokument ma uszkodzenia w formie dziur, których liczba i rozmiar wzrastają aż do ostatniej strony. Sądząc po uszkodzeniach, dziury spowodowane zostały wcześniejszym podłużnym złożeniem dokumentu. Na załamaniu widać ślady żerowania gryzoni. Sznurek łączący karty jest brudny, a pieczęć lakowa połamana i wykruszona w ok. 50\%. Dokument wymaga zabiegów konserwatorskich.

$$
* * *
$$

[s. 1] Wizyta Kościoła Parafialnego Rzymsko-Katolickiego Dywinskiego przez naznaczonego wizytatora, księdza Antoniego Kisielewskiego ${ }^{5}$ proboszcza kobryńskiego, za rok 1844 odprawiona.

\section{Kościól parafialny rzymsko-katolicki dywiński V. klasy ${ }^{6}$}

a) Kościół parafialny rzymsko-katolicki dywiński, położony w gubernii gro-

${ }^{5}$ Ks. Kisielewski Antoni - budowniczy kościoła pw. Zaśnięcia NMP w Kobryniu, wzniesionego w latach 1841-1845. Projekt budowy murowanego kościoła nie został zatwierdzony przez Synod Ruskiej Prawosławnej Cerkwii i w 1838 roku zwrócono go administratorowi diecezji wileńskiej (biskupowi pomocniczemu z Wilna) Andrzejowi Kłągiewiczowi (1761-1841) do poprawienia. Synod nie był przeciwny budowie samego kościoła, ale obawiając się wpływów katolickich na wiernych prawosławnych, zalecił jego budowę na przedmieściu - na ul. Pińskiej, czyli w miejscu obecnej lokalizacji. Po zatwierdzeniu w maju 1840 roku projektu przez architekta Nostowa, w pierwszym półroczu następnego roku rozpoczęto jego budowę, która trwała 4 lata. Dnia 15 VIII 1845 roku kościół został poświęcony przez proboszcza i budowniczego, ks. Antoniego Kisielewskiego. Jego konsekracji dokonał w 1851 roku biskup wileński Wacław Żyliński i nadał mu wezwanie Wniebowzięcia NMP. M. Kitajczuk, Burzliwe dzieje Polesia, Wrocław 2002, s. 52.

${ }^{6}$ Ukaz carski z 1 I 1843 roku podzielił biskupstwa w Cesarstwie Rosyjskim na trzy klasy. Od nich wyznaczono wysokość uposażenia diecezji, biskupa i jego współpracowników. Kolejny ukaz z 15 grudnia tego roku wyznaczył uposażenie parafii i niższego duchowieństwa diecezjalnego. Jego mocą parafie zostały podzielone na pięć klas, a proboszczom parafii z poszczególnych klas wyznaczono pensję etatową w wysokości od 235 do 600 rubli rocznie. Ponadto każdemu proboszczowi pozostawiono pewien areał gruntów lub w zamian specjalny zasiłek ze skarbu państwa. Zdecydowana większość parafii należała do klasy V. Księża dziekani z racji wypełniania swoich obowiązków, w tym i przeprowadzanych wizytacji, pobierali 5\% od pensji proboszczowskiej. Por. Litak, Kościót łaciński w Rzeczypospolitej około 1772 roku, Lublin 1996, s. 78-79.

Proboszczowie dywińscy pobierali więc najniższe uposażenie przysługujące w klasie piątej parafii: 230 rubli, skromny dochód w wydzielonej i pozostawionej do dyspozycji ziemi i ofiar złożonych przy spełnianiu posług duchowych parafianom. B. Kumor, Ustrój i organizacja Kościoła polskiego w okresie niewoli narodowej 1772-1918, Kraków 1980, s. 306; F. Sznarbachowski, Początek i dzieje Rzymsko-Katolickiej Djecezji Łucko-Żytomierskiej, obecnie Łuckiej, w zarysie, Warszawa 1926, s. 237. 
dzieńskiej, w powiecie i dekanacie kobryńskim, w miasteczku Dywinie, drewniany, roku 1728 przez księdza Jana Antoniego Wojewodzkiego 7 plebana dywińskiego zbudowany $\mathrm{w}$ figurze ${ }^{8}$ prostokąta $\mathrm{z}$ dwoma bocznemi skrzydłami, i z kopułą w części blachą obitą, w części zielono malowaną: na której żelazny krzyż w promieniach. Ma długości arszynów ${ }^{9} 28$, szerokości 18 arszynów. Dach gontami ${ }^{10}$ pokryty: na którym drewniany z frontu krzyż z końcami blachą obitemi. Ściany zewnątrz tarcicami ${ }^{11}$ opierzone. Wewnątrz kościoła dwa przedziały, to jest skarbczyk i zakrystia. Okien w ogólności różnej wielkości dziewiętnaście: z tych siedemnaście w drzewo, a dwa w zakrystyi w ołów oprawione, w skarbczyku i w zakrystyi żelaznemi kratami opatrzone. [s. 2] Podłoga i stolowanie ${ }^{12} \mathrm{z}$ tarcic. W skarbczyku posadzka z cegły z małym ceglanym kominkiem. Ołtarzów pięć: z tych ołtarz wielki stolarskiej roboty, biało malowany, z rzeźbą pozłacaną o czterech filarach, blachą mosiężną powleczonych, $\mathrm{z}$ dwóma po bokach snycerskiej roboty biało malowanemi, częścią pozłacanemi archaniołami, i z dwóma na gzemsach takiejże roboty i malowidła wazonami. W nim obraz ukrzyżowanego Zbawiciela w biało malowanych, w części pozłacanych stolarskiej roboty ramach: nad którym obraz Boga Ojca, a nad nim Opatrzność w obłokach z pozłacanemi promieniami. Cyborium ${ }^{13}$ niebiesko malowane, częścią pozłacane $\mathrm{z}$ wyobrażeniem ŚS. Ducha. Prezbiterium przegrodą stolarskiej roboty, biało i ciemno malowaną opatrzone. Za niem z prawej strony, przy ścianie skarbczyka, drugi ołtarz snicerskiej roboty o dwóch filarach, błękitno malowany, z rzeźbą w części posrebrzaną, i w części pozłacaną. W nim obraz Najświętszej Matki z Ś. Józefem i Panem Jezusem w ramach snicerskiej roboty pozłacanych. Na wierzchu Opatrzność błękitno malowana w ramach okrągłych snicerskiej roboty pozłacanych. Nad mensą ${ }^{14}$ krzyżyk w szklanej flaszeczce z całym przyborem cierpienia Chrystusa Pana. Z lewej - prezbiterium strony trzeci takiż we wszystkich szczegółach ołtarz z obrazem Ś. Michała Archanioła: nad którym obraz Ś. Jana Nepomucena, a na wierzchu ptak

${ }^{7}$ Ks. Wojewódzki Jan Antoni, jako kooperator wspomagał od 1722 roku w Dywinie proboszcza ks. Benedykta Rusieckiego (1721-1827), a od 1728 roku został tam proboszczem. Jego staraniem został wzniesiony drewniany kościół pw. Oczyszczenia Najświętszej Maryi Panny w Dywinie, którego poświęcenia dokonał w 1743 roku biskup łucki Franciszek Antoni Kobielski (1679-1755).

${ }^{8} \mathrm{~W}$ figurze $-\mathrm{w}$ kształcie, na planie.

${ }^{9}$ Arszyn - dawna jednostka miary długości, równa 1 metra, używana w Rosji przed 1918 rokiem i w kilku innych krajach przed wprowadzeniem systemu metrycznego (w Polsce w 1919 roku).

${ }^{10}$ Gont - deszczułka klinowa używana do pokrywania dachów lub szalowania zewnętrznych ścian budynków.

${ }^{11}$ Tarcica - materiał drzewny otrzymany poprzez pocięcie okrąglaków równolegle do ich osi podłużnych; jedna z desek otrzymanych w ten sposób.

${ }^{12}$ Stalować (niem. stellen) - przestarzałe: zlecać wykonanie czegoś.

${ }^{13}$ Cyborium - w architekturze sakralnej rodzaj baldachimu. Baldachimowa obudowa architektoniczna, wznoszona w kościołach nad ołtarzami, grobami świętych, chrzcielnicami lub relikwiarzami. Cyborium wykonywane było głównie z drewna i kamienia.

${ }^{14}$ Mensa (łac. stół) - kamienna płyta tworząca z podstawą (stipes) ołtarz. Była wykonywana z drewna, od VII wieku z kamienia. Od średniowiecza w niszy mensy (sepulcrum) umieszczano relikwie męczenników. Miejsce to całował celebrans przed sprawowaniem Eucharystii i po jej zakończeniu. 
pelikan, karmiący swoje pisklęta. Ołtarz ten przez teraźniejszego plebana zupełnie odnowiony. Przy bocznych kościoła ścianach naprzeciw sobie położone dwa ołtarze: oba stolarskiej roboty, o dwóch trójkątnych filarach, brązowo malowane, częścią pozłacane: w jednym z nich obraz Ś. Wojciecha, z obrazem na wierzchu Ś. Antoniego Padewskiego, a w drugim obraz Ś. Piotra [s. 3] Apostoła z malowaną na górze infułą papieską ${ }^{15}$. Wszystkie te ołtarze mosiężną blachą są ozdobione i wszystkie potrzebnemi obrusami, krzyżami, tablicami (prócz jednej Ewangelii) kanony zwanemi, portatylami ${ }^{16}$, poduszeczkami i pokryciami z perkalu opatrzone. W prezbiterium z prawej wielkiego ołtarza strony ambona stolarskiej roboty, biało malowana, z rzeźbą pozłacaną. Nad nią baldachim ${ }^{17}$ takiejże roboty i malowidła z osobą pasterza, trzymającego na ramionach jagnię, snicerskiej roboty. Naprzeciw ambony chrzcielnica $\mathrm{w}$ figurze wazona na podstawie biało malowanej stolarskiej roboty o dwóch gradusach ${ }^{18}$. Nad nią takiż jak i nad amboną baldachim z wyobrażeniem Zbawiciela, przyjmującego od Ś. Jana chrzest w Jordanie w obecności Ś. Ducha. Cała ta sztukatura ${ }^{19}$ snicerskiej roboty, biało malowana, częścią pozłacana. Wyżej ambony i chrzcielnicy nad prezbiterium drewniana tęcza, wyobrażająca kalwaryjską górę, na której drewniany krzyż z męką Zbawiciela ordynaryjnej ${ }^{20}$ snicerskiej roboty, z osobami Najświętszej Panny i Ś. Jana Apostoła, na deskach malowanemi. Organ ${ }^{21}$ dwumiechowy o dziesięciu głosach, z chórem stolarskiej roboty, błękitno malowanym, na dwóch drewnianych słupach spartym. Drzwi w ogóle cztery: $\mathrm{z}$ tych drzwi wielkie podwójne futrowane, drewnianym drągiem w klamry żelazne ze śrzodka zamykające się. Dwoje drzwi przy skarbczyku, jedne zewnątrz, a drugie prowadzące do prezbiterium, i jedne przy zakry-

${ }^{15}$ Infuła (mitra) - liturgiczne nakrycie głowy biskupa w formie trójkątnej czapki złożonej z dwóch płatów, złączonych materiałem. Z tylnego płatu zwisają swobodnie na plecy biskupa dwie wstęgi. Początkowo nosili je papieże, jednak nie jako strój liturgiczny. Od pontyfikatu Leona IX (od XII w.) używana jest jako strój liturgiczny.

${ }^{16}$ Portatyl (łac. altare portatile) - wykonywane od VII wieku małe, przenośne ołtarzyki, głównie metalowe lub z kości słoniowej, używane w czasie podróży do sprawowania liturgii mszalnej. W późniejszym okresie ołtarz ten został zastąpiony zestawem miniaturowych sprzętów mszalnych wykorzystywanych przez kapelanów wojskowych lub duchownych do udzielania sakramentu chorych, tzw. wiatyku. Portatyl musiał być wykonany z jednolitej bryły kamienia na tyle grubej, aby w środku znalazło się miejsce na relikwie, a na nim kielich i hostia, a także puszka z komunikantami do konsekracji.

${ }^{17}$ Baldachim - dekoracyjny, ochronny daszek z materiału rozpięty na drążkach, przeznaczony do niesienia lub umocowania nad tronem, ołtarzem, katafalkiem, W liturgii występuje baldachim przenośny lub stały. W sztuce kościelnej stosowano najrozmaitsze formy baldachimu: jako dach ochronny nad ołtarzem, chrzcielnicą lub grobem (cyborium), grobami świętych, relikwiarzami (konfesją), nad amboną (daszek) lub stallami (zwieńczenie zaplecków).

${ }^{18}$ Gradus - stopień.

${ }^{19}$ Sztukateria - dekoracja architektoniczna (np. rzeźby, rozety, gzymsy) ścian, sklepień, sufitów itp. wykonana w gipsie lub stiuku techniką narzutową lub metodą odlewu.

${ }^{20}$ Ordynaryjny - zwyczajny.

${ }^{21}$ Organ - tu: organy. 
styi. Wszystkie te drzwi stolarskiej roboty na zawiasach i krukach ${ }^{22}$ żelaznych, i wszystkie, oprócz wielkich, z wnętrznemi zamkami. Cały kościół wewnątrz częścią biało, częścią błękitno i częścią zielono malowany.

Uwaga. Kościół stary, na prawą stronę nieco nachylony: potrzebuje podważenia, nowego zmocnienia słupami ścian, nowego opie[rzenia i przesypania da$\mathrm{chu}$.

[s. 4] Opisanie ornatów, kap, itd.

\begin{tabular}{|c|c|c|}
\hline L.p. & Ornaty białe & Sztuki \\
\hline 1. & $\begin{array}{l}\text { Ornat lamy }{ }^{\mathrm{a}} \text { srebrnej w karpiową łuskę w kwiatki zielone, z kampanką }{ }^{\mathrm{b}} \text { złotą, } \\
\text { zieloną kitajką }{ }^{\mathrm{c}} \text { podszyty, z garniturem }{ }^{\mathrm{d}} \text {, jeden }\end{array}$ & 1. \\
\hline 2. & $\begin{array}{l}\text { Ornat parterowy } \mathrm{w} \text { złoto-różowe kwiaty, z kolumną lamy złotej, z galonem } \\
\text { złotym, niebieską kraszaniną podszyty, z garniturem, jeden }\end{array}$ & 1. \\
\hline 3. & $\begin{array}{l}\text { Ornat parterowy w złoto-zielone kwiaty, z kolumną złotej lamy, z galonem złotym, } \\
\text { różową kitajką podszyty, z dobranym garniturem, jeden }\end{array}$ & 1. \\
\hline 4. & $\begin{array}{l}\text { Ornat lamy złotej w srebrne kwiaty, } \mathrm{z} \text { galonem złotym, podszyty materią } \\
\text { grodeturową }{ }^{\mathrm{g}} \text {, bez rekwizytów, jeden }\end{array}$ & 1. \\
\hline 5. & $\begin{array}{l}\text { Ornat półzłotej lamy w takież kwiatki na plamkach niebieskich, z galonem } \\
\text { szychowym }{ }^{\mathrm{h}} \text {, różową kitajką podszyty, z garniturem atłasu żółtego, jeden }\end{array}$ & 1. \\
\hline
\end{tabular}

${ }^{22}$ Kruk (z ros. крюк) - gruby metalowy pręt z zagiętą końcówką, hak.

${ }^{\text {a }}$ Lama - gładka lub wzorzysta tkanina jedwabna o tle całkowicie lub częściowo pokrytym dodatkowym wątkiem metalowym złotym lub srebrnym, wyjątkowo obydwoma, często w postaci pasków folii. W wyrobach najlepszej jakości wątki są niewidoczne. Wzory drobne, geometryczne, np. kwadraty, szachownica, ,rybia łuska”. W inwentarzach polskich lama bywa określana zwykle według koloru przędzy jedwabnej widocznej spod wątków metalowych. Używana na bogate ubiory męskie i suknie damskie, na szaty liturgiczne od XVIII wieku po dzień dzisiejszy.

${ }^{\mathrm{b}}$ Kampanka, kampana, kompana - rodzaj wąskiej koronki klockowej, wyrabianej w oparciu o najłatwiejsze przeploty koronkowe. Wytwarzana we Francji w XVII-XVIII wieku, w Polsce w XVIII wieku.

${ }^{\mathrm{c}}$ Kitajka (z ros. Китай - Chiny) - cienka, dość gęsta, gładka, lśniąca tkanina bawełniana lub jedwabna o splocie płóciennym, jednobarwna lub mieniąca się (wątek różni się barwą od osnowy). Najprostsza i najpospolitsza z tkanina jedwabnych, cieńsza i zwykle gorsza gatunkowo od tafty. Wyrabiana na Wschodzie, sprowadzana do Polski w XVII wieku z Turcji, w następnym stuleciu wyrabiana w Grodnie.

${ }^{\mathrm{d}}$ Garnitur - w znaczeniu liturgicznym: komplet szat liturgicznych (ornat, dalmatyki i kapa).

${ }^{e}$ Part - gruba tkanina konopna lub lniana z najgrubszych pakuł uzyskiwanych przy klepaniu lnu, zgrzebna, niebielona. W dawnej Polsce wyrabiana w domowych warsztatach. Używana na najtańszą odzież ludu wiejskiego i ubrania robocze.

${ }^{\mathrm{f}}$ Galon (z franc.) - wyrób pasamoniczny w formie gładko lub wzorzyście tkanej, rzadziej plecionej taśmy wykonanej z nitek jedwabnych, bawełnianych i metalowych; naszywka z taśmy srebrnej albo złotej na mundurkach, tutaj na ornacie.

${ }^{g}$ Grodetur, gradytur, gredytur, grodytur, drodetur (franc. gros de Tours) - gęsta tkanina jedwabna o splocie grodeturu, rodzaj kitajki średniej grubości, barwiona na różne kolory, czasem wzorzysta (broszowanie). Importowana z Francji (m.in. z Tours) od XVI wieku, w 2 połowie XVIII wieku wytwarzana w manufakturze grodzieńskiej. Używana jako odzieżowa, niekiedy jako tło do haftów.

${ }^{\text {h }}$ Szych - fałszywe złoto lub srebro używane do wyrobu galonów, haftów itp.; przędza (nitka) Iniana lub bawełniana okręcona spiralnie paseczkiem miedzianym posrebrzonym lub pozłoconym, używana do haftów i wyrobów pasmanteryjnych, np. miedziany, srebrny szych. 


\begin{tabular}{|c|c|c|}
\hline 6. & $\begin{array}{l}\text { Ornat materyi szychowej żółtej, z galonem złotym, z dobranym garniturem } \\
\text { materyi żółtej, ciemną kraszaniną podszyty, jeden }\end{array}$ & 1. \\
\hline 7. & $\begin{array}{l}\text { Ornat z pasa tureckiego lamy złotej z atłasowym garniturem, popielatą kitajką } \\
\text { podszyty, jeden }\end{array}$ & 1. \\
\hline 8. & $\begin{array}{l}\text { Ornat parterowy popielaty, z galonem białym szychowym, zieloną kitajką } \\
\text { podszyty, bez garnituru, jeden }\end{array}$ & 1. \\
\hline 9. & $\begin{array}{l}\text { Ornat parterowy w różne kwiatki, z kolumną niebieskiej materyi, z galonem } \\
\text { szychowym, różową kraszaniną podszyty, z garniturem, jeden }\end{array}$ & 1. \\
\hline 10. & $\begin{array}{l}\text { Ornat parterowy w kwiatki złoto-różowe, z kolumną materyi fioletowej, niebieską } \\
\text { kraszaniną podszyty, z garniturem, jeden }\end{array}$ & 1. \\
\hline 11. & $\begin{array}{l}\text { Ornat szychowy w złote fale, } \mathrm{z} \text { kolumną ponsową }{ }^{\mathrm{i}} \mathrm{w} \text { różne kwiatki, popielatą } \\
\text { kitajką podszyty, z garniturem, jeden }\end{array}$ & 1. \\
\hline 12. & $\begin{array}{l}\text { Ornat parterowy w kwiatki zielone, z kolumną fioletową, [s. 5] popielatą kitajką } \\
\text { podszyty, z dobrym garniturem, jeden }\end{array}$ & 1. \\
\hline 13. & $\begin{array}{l}\text { Ornat parterowy w różne kwiatki, z galonem szychowym, podszyty kraszaniną, } \\
\text { bez garnituru, oprócz welum, jeden }\end{array}$ & 1. \\
\hline 14. & $\begin{array}{l}\text { Ornat parterowy, z takąż kolumną białej materyi, z galonem białym szychowym, } \\
\text { popielatą kraszaniną podszyty, z garniturem dobranym, jeden }\end{array}$ & 1. \\
\hline 15. & $\begin{array}{l}\text { Ornat grodeturowy, z kolumną niebieską w różane kwiatki, z galonem białym } \\
\text { szychowym, niebieską kraszaniną podszyty, z garniturem dobranym, jeden }\end{array}$ & 1. \\
\hline 16. & $\begin{array}{l}\text { Ornat grodeturowy żółty, z kolumną parterową białą, z galonem żółtym } \\
\text { szychowym, ciemną kitajką podszyty, z garniturem, jeden }\end{array}$ & 1. \\
\hline 17. & $\begin{array}{l}\text { Orant z pasa tureckiego w różne kwiaty, popielatą kitajką podszyty, bez garnituru, } \\
\text { jeden }\end{array}$ & 1. \\
\hline 18. & $\begin{array}{l}\text { Ornat grodeturowy z wyszytą męką Chrystusa, z galonem złotym, różową kitajką } \\
\text { podszyty, z garniturem, jeden }\end{array}$ & 1. \\
\hline 19. & $\begin{array}{l}\text { Ornat w paski zielono-fioletowe, } \mathrm{z} \text { kolumną w kwiatki biało-zielone, z galonem } \\
\text { szychowym białym, popielatą kitajką podszyty, z garniturem, jeden }\end{array}$ & 1. \\
\hline 20. & $\begin{array}{l}\text { Ornat szychu żółtego w ponsowo-zielone kwiatki, z galonem srebrnym, białą } \\
\text { kitajką podszyty, z dobranym garniturem, jeden }\end{array}$ & 1. \\
\hline 21. & $\begin{array}{l}\text { Ornat białej materyi w zielone paski, z galonem szychowym, zieloną kraszaniną } \\
\text { podszyty, z garniturem, jeden }\end{array}$ & 1. \\
\hline \multicolumn{3}{|c|}{ Ornaty czerwone } \\
\hline 22. & $\begin{array}{l}\text { Ornat parterowy różowy, z kolumną materyi burakowej, z kampanką srebrną, } \\
\text { różową kitajką podszyty, z garniturem dobranym, jeden }\end{array}$ & 1. \\
\hline 23. & $\begin{array}{l}\text { Ornat aksamitny w złote kwiaty z kolumną takąż zieloną, złotem haftowaną, } \\
\text { z galonem złotym, różową kitajką podszyty, z garniturem dobranym, jeden }\end{array}$ & 1. \\
\hline 24. & $\begin{array}{l}\text { [s. 6] Ornat aksamitny, z kolumną lamy złotej w kwiatki, z galonem szychowym, } \\
\text { czerwoną kraszaniną podszyty, z garniturem, jeden }\end{array}$ & 1 \\
\hline 25. & $\begin{array}{l}\text { Ornat atłasowy w różne żółto-szychowe paski, z kolumną białą, z kampanką } \\
\text { szychową, czerwoną kraszaniną podszyty, z dobranym garniturem, jeden }\end{array}$ & 1. \\
\hline 26. & $\begin{array}{l}\text { Ornat atłasowy w różne kwiaty, z kolumną materyi białej, pikowany w kwiaty, } \\
\text { z kampanką po brzegach szychową, ciemną astrachanią podszyty, z garniturem, } \\
\text { jeden }\end{array}$ & 1. \\
\hline 27. & $\begin{array}{l}\text { Ornat atłasowy w kwiaty szychowe, z kolumną parterową białą, w kwiaty zielono- } \\
\text { różowe, ciemną kitajką podszyty, z garniturem, jeden }\end{array}$ & 1. \\
\hline
\end{tabular}

i Pons (wł.) - pąsowy, ciemnoczerwony zgaszony.

j Astrachan - tkanina, rodzaj pluszu o podstawie bawełnianej z okrywą włosową z przędzy moher; futro ze skórek młodego barana astrachańskiego. 


\begin{tabular}{|c|c|c|}
\hline 28. & $\begin{array}{l}\text { Ornat atłasowy w kwiaty złote, z kolumną parterową białą w kwiaty, z galonem } \\
\text { naturalnym, ciemną kitajką podszyty, z garniturem, jeden }\end{array}$ & 1. \\
\hline 29. & $\begin{array}{l}\text { Ornat parterowy w kwiaty srebrne, z kolumną niebieską w kwiaty białe, z galonem } \\
\text { szychowym, czerwoną astrachanią podszyty, z garniturem dobranym, jeden }\end{array}$ & 1. \\
\hline 30. & $\begin{array}{l}\text { Ornat atłasowy w różne paski żółto-szychowe, z kolumną niebieską, w kwiatki } \\
\text { ciemno-zielone, z galonem szychowym żółtym, zieloną kitajką podszyty, } \\
\text { z dobranym garniturem, jeden }\end{array}$ & 1 . \\
\hline \multicolumn{3}{|c|}{ Ornaty fioletowe } \\
\hline 31. & $\begin{array}{l}\text { Ornat sztofowy }{ }^{\mathrm{k}} \text { w kwiaty złoto-srebrne, z kampanką szychową, różową kitajką } \\
\text { podszyty, z garniturem, jeden }\end{array}$ & 1. \\
\hline 32. & $\begin{array}{l}\text { Ornat sztofowy w kwiaty srebrne, z galonem srebrnym, zieloną kitajką podszyty, } \\
\text { z garniturem, jeden }\end{array}$ & 1. \\
\hline 33. & $\begin{array}{l}\text { Ornat parterowy w różne kwiaty, z galonem białym szychowym, niebieską } \\
\text { astrachanią podszyty, z garniturem, jeden }\end{array}$ & 1. \\
\hline 34. & $\begin{array}{l}\text { Ornat parterowy w kwiaty, z kolumną czerwoną w kwiaty złote, z kampanką } \\
\text { szychową, żółtą astrachanią podszyty, z garniturem, jeden }\end{array}$ & 1. \\
\hline \multicolumn{3}{|c|}{$[\mathrm{s} .7]$ Ornaty zielone } \\
\hline 35. & $\begin{array}{l}\text { Ornat aksamitny z kolumną białą w róże, z kampanką białą szychową, zieloną } \\
\text { kitajką podszyty, z garniturem, jeden }\end{array}$ & 1. \\
\hline 36. & $\begin{array}{l}\text { Ornat w pasy białe z kolumną białą lamy srebrnej w kwiaty, z galonem szychowym } \\
\text { białym, czerwoną astrachanią podszyty, z garniturem, jeden }\end{array}$ & 1. \\
\hline 37. & $\begin{array}{l}\text { Ornat atłasowy w pasy zielono-niebieskie z kolumną lamy żółtej, z galonem } \\
\text { szychowym, popielata kitajką podszyty, bez rekwizytów, jeden }\end{array}$ & 1. \\
\hline 38. & $\begin{array}{l}\text { Ornat sztofowy w kwiatki różowe z kolumną szychową czerwoną, w kwiatki, } \\
\text { z galonem szychowym, czerwonym mamisem podszyty, z garniturem, jeden }\end{array}$ & 1. \\
\hline \multicolumn{3}{|c|}{ Ornaty żałobne } \\
\hline 39. & $\begin{array}{l}\text { Ornat racemorowy }{ }^{\mathrm{m}} \mathrm{w} \text { pasy, } \mathrm{z} \text { kolumną materyi białej jedwabnej } \mathrm{w} \text { czarne paski, } \\
\mathrm{z} \text { galonem szychowym białym, ciemnym mamisem podszyty, } \mathrm{z} \text { garniturem, } \\
\text { jeden }\end{array}$ & 1. \\
\hline 40. & $\begin{array}{l}\text { Ornat nędzy }{ }^{\mathrm{n}} \text { ruskiej, z kolumną materyi ciemnofioletowej w różne szychowe } \\
\text { kwiaty, z tasiemką czarną, astrachanią podszyty, z garniturem, jeden }\end{array}$ & 1. \\
\hline 41. & $\begin{array}{l}\text { Ornat adamaszkowy, z kolumną, ciemnej materyi w paski zielone, z galonem } \\
\text { szychowym, czarną astrachanią podszyty, z dobranym garniturem, jeden }\end{array}$ & 1. \\
\hline 42. & $\begin{array}{l}\text { Ornat materyi ciemnofioletowej w różne szychowe kwiaty, z galonem szychowym, } \\
\text { popielatą kitajką podszyty, bez garnituru, jeden }\end{array}$ & 1. \\
\hline
\end{tabular}

${ }^{\mathrm{k}}$ Sztof - tkanina jedwabna, bławat.

${ }^{1}$ Mamisem, zapewne błędnie zamiast: tamisem. Tamis - tkanina z długiej wełny czesankowej dobrego gatunku.

${ }^{\mathrm{m}}$ Ratyna (fr. ratine) - tkanina wełniana z przędzy czesankowej dobrego gatunku, z krótkim, fryzowanym włosem uzyskanym $w$ efekcie ratynowania (jeden $\mathrm{z}$ ostatnich etapów wykańczania tkanin i dzianin wełnianych i półwełnianych). Tkanina wysokiej jakości, dawniej importowana np. z Francji, Prus. Od ok. 1770 wyrabiana także w polskich manufakturach.

${ }^{\mathrm{n}} \mathrm{Nędza} \mathrm{-} \mathrm{dawniej} \mathrm{potocznie:} \mathrm{tkanina} \mathrm{jedwabna} \mathrm{lub} \mathrm{półjedwabna} \mathrm{szychem} \mathrm{przerobiona} \mathrm{w} \mathrm{gor-}$ szy gatunek alheruntu. 


\section{Kapy:}

\begin{tabular}{|l|l|c|}
\hline 1.p. & \multicolumn{1}{|c|}{ Kapy } & Sztuki \\
\hline 1. & $\begin{array}{l}\text { Kapa materyi parterowej popielaty, z szczytem materyi niebieskiej w kwiaty } \\
\text { srebrne, z kampanką złotą, różowym mamisem podszyta, z klamerką srebrną, } \\
\text { jedna }\end{array}$ & 1. \\
\hline 2. & $\begin{array}{l}\text { [s. 8] Kapa materyi parterowej białej w różne kwiaty, z szczytem takiejże materii } \\
\text { w kwiaty srebrnoróżowe, z galonem szychowym, żółtą astrachanią podszyta, } \\
\text { z klamerką srebrną, jedna }\end{array}$ & 1. \\
\hline 3. & $\begin{array}{l}\text { Kapa atłasowa w pasy ponsowo-fioletowe, z galonem żółtym szychowym, } \\
\text { popielatym mamisem podszyta, z klamerką blaszaną, jedna }\end{array}$ & 1. \\
\hline 4. & $\begin{array}{l}\text { Kapa ciemnej materyi w paski atłasowe, z szczytem materyi w paski biało- } \\
\text { fioletowe, z galonem szychowym, kitajką podszyta, z klamerką blaszaną, jedna }\end{array}$ & 1. \\
\hline 5. & $\begin{array}{l}\text { Kapa racemorowa czarna, z szczytem aksamitnym czarnym, z galonem szychowym } \\
\text { białym, czarną astrachanią podszyta, z klamerką blaszaną, jedna }\end{array}$ & 1. \\
\hline
\end{tabular}

\section{Opisanie bielizny kościelnej i dalszego ubioru:}

\begin{tabular}{|l|c|}
\hline $\begin{array}{l}\text { Alb w ogóle ośm: z tych muślinowych }{ }^{\circ} \text { trzy, perkalowych dwie, obrąbkowa jedna } \\
\text { i płóciennych dwie }\end{array}$ & 8. \\
\hline Komż kapłańskich: płócienna jedna i dwie perkalowe, w ogóle trzy & 3. \\
\hline Komż dla chłopców perkalowych dwie & 2. \\
\hline $\begin{array}{l}\text { Tuwalnip w ogóle siedemnaście: z tych jedna jedwabna różowa z takiemiż frędzlami, } \\
\text { muślinowych pięć, perkalowych cztery i płóciennych siedem }\end{array}$ & 17. \\
\hline Ręczników ołtarzowych różnego płótna piętnaście & 15. \\
\hline Ręczników do lawaterza siedm & 7. \\
\hline $\begin{array}{l}\text { Korporałów w ogóle jedenaście: z tych batestowy jeden, trzy płótna holenderskiego, } \\
\text { i siedm płótna tkackiego }\end{array}$ & 11. \\
\hline Puryfikaterzy różnego płótna trzydzieści & 30. \\
\hline Humerałów różnego płótna ośm & 8. \\
\hline Pasków różnych siedm & 7. \\
\hline Tabernakulów różnych cztery & 4. \\
\hline Welon pod krzyż na wielki ołtarz różnych cztery & 4. \\
\hline [s. 9.] Antependiówt różnych sześć & 6. \\
\hline Bursa do chorych stara jedna & 1. \\
\hline Sukno czerwone na gradusy wielkiego ołtarza z pięcią kawałkami, w ogóle sześć & 6. \\
\hline Całun z dymyw ciemnej z czerwonym we środku krzyżem, jeden & 1. \\
\hline \multicolumn{1}{|c|}{ Dalszy sprzęt kościelny } \\
\hline $\begin{array}{l}\text { Ołtarzyk do procesyi snicerskiej roboty z obrazem z jednej strony ŚŚ Trójcy, a z drugiej } \\
\text { S. Mikołaja z firankami muślinowemi, jeden }\end{array}$ & 1. \\
\hline $\begin{array}{l}\text { Baldachim z szczytem czerwonej materyi, śrzodkiem i brzegami materyi szychowej } \\
\text { żółtej w paski fioletowe o dwóch rękojeściach, jeden }\end{array}$ & 1. \\
\hline Chorągwi różnych trzy & 3. \\
\hline $\begin{array}{l}\text { Gradusów przedołtarzowych w ogóle siedm: z tych przy wielkim ołtarzu trzy, i po dwa } \\
\text { przy ołtarzach Najświętszej Panny i Ś. Michała; wszystkie stolarskiej roboty }\end{array}$ & 7. \\
\hline $\begin{array}{l}\text { Ławek stolarskiej roboty w ogóle dziesięć: z tych brązowo malowane w presbiterium } \\
\text { i na śrzodku kościoła z lewej i prawej strony po cztery }\end{array}$ & 10. \\
\hline Krzesło z paręczami skórą obite jedno & 1. \\
\hline
\end{tabular}

${ }^{\circ}$ Muślin (franc.) - delikatna, przezroczysta tkanina jedwabna, rzadziej bawełniana, o luźnym splocie płóciennym, zwykle jednobarwna, czasem drukowana.

p Tuwalnia (wł.) - rodzaj ręcznika, przez który kapłan trzyma monstrancję. 


\begin{tabular}{|l|c|}
\hline $\begin{array}{l}\text { Szafka przy chrzcielnicy na czterech słupkach z kratkami w postaci pulpitu stolarskiej } \\
\text { roboty, mahoniowo malowana, jedna }\end{array}$ & 1. \\
\hline Lichtarz drewniany stolarskiej roboty, malowany, do paschału, jeden & 1. \\
\hline Konfesjonałów stolarskiej roboty niebiesko malowanych, dwa & 2. \\
\hline Krzyż do procesyi drewniany ciemno-malowany z pasyjką bronzową, jeden & 1. \\
\hline $\begin{array}{l}\text { Krzyż drewniany na podstawie w postaci skały z pasyjką [s. 10] mosiężną biało } \\
\text { malowany, częścią pozłacany jeden }\end{array}$ & 1. \\
\hline Triangułów do lamp większych dwa i tyleż mniejszych, w ogóle cztery & 4. \\
\hline Komoda w zakrystyi stolarskiej roboty z dziewięcią szufladami, jedna & 1. \\
\hline Skrzyń z wiszącymi zamkami dwie & 2. \\
\hline Podstawka do miednicy nowa o trzech nóżkach malowana, stolarskiej roboty, jedna & 1. \\
\hline Scabellum o trzech stopniach jedno & 1. \\
\hline Maryz ordynaryjnej ciesielskiej roboty jedne & 1. \\
\hline Latarni do procesyi z rękojeściami pojedynczemi cztery & 4. \\
\hline
\end{tabular}

r Batyst (franc. od imienia wynalazcy Baptiste'a Chambray) - cienka tkanina, zwykle lniana lub bawełniana, jednobarwna albo wzorzysta, używana także na bieliznę liturgiczną.

s Tabernakulum (łac. mały namiot) - w kościołach rzymskokatolickich mała, zamykana na klucz szafka stojąca pośrodku tylnego brzegu mensy ołtarzowej, przeznaczona do przechowywania hostii i komunikantów. Zwykle wykonywane z drewna, wewnątrz obijane białym jedwabiem. W średniowieczu wmurowywano niekiedy tabernakulum w ścianę obok ołtarza głównego. Tabernakulum wmurowane lub wolno stojące zwane jest czasem błędnie cyborium.

${ }^{t}$ Antependium, antepedium (od łac. ante pedes przed stopami) - zasłona ścianki frontowej ołtarza.

u Bursa (łac. mieszek) - sztywna torebka z tkaniny lub koperta ze sztywnego materiału, w której prezbiter, diakon lub akolita zanosi Komunię Świętą do chorych. Jest zawieszana na szyi i widoczna dla przechodzących obok szafarza, by mogli oni oddać cześć niesionemu Ciału Pańskiemu.

${ }^{w}$ Dyma (dymka) - tkanina lniana, bawełniana o lnianej osnowie i bawełnianym wątku lub konopn a, głównie biała, potem też kolorowa. Pochodzi ze Wschodu. Do Polski sprowadzona od XVI do XVIII, wyrabiana w Małopolsce w XVIII wieku, a w XIX wieku w wielu ośrodkach płóciennictwa.

x Triangulus (łac.) - trójkąt, tu w znaczeniu: podstawka na świece.

${ }^{\text {y }}$ Scabellum (łac.) - podnóżek, stołeczek, ławeczka.

${ }^{z}$ Mary - nosze dla zmarłych, także podwyższenie na którym ustawia się trumnę lub trumna ze zwłokami stająca na podwyższeniu. 


\section{Opisanie klejnotów, złota, srebra itd.}

Klejnotów, prócz trzech kamuszków czeskich w koronach obrazu Matki Boskiej, nie ma.

\begin{tabular}{|c|c|c|c|}
\hline Srebro & ㅈ. $\underset{\mathbb{N}}{\mathbb{E}}$ & 民 & $\stackrel{7}{2}$ \\
\hline $\begin{array}{l}\text { Monstrancja w figurze arki pozłacana próby szóstej jedna, waży funtów } \\
\text { cztery, łutów dwadzieścia dwa }\end{array}$ & 1. & 4. & 22. \\
\hline $\begin{array}{l}\text { Puszka do Sanctissimum wewnątrz i zewnątrz wyzłacana, próby szóstej } \\
\text { jedna, waży funt jeden }\end{array}$ & 1. & 1. & \\
\hline $\begin{array}{l}\text { Kielichów cztery: z tych próby szóstej trzy, jeden wewnątrz, a dwa } \\
\text { i zewnątrz wyzłacane, czwarty próby trzynastej matowej roboty, z częścią } \\
\text { kamuszkami granatkami wewnątrz i zewnątrz wyzłacany, i cztery do } \\
\text { nich pateny próby szóstej, wszystkie w ogólności ważą funtów pięć, } \\
\text { łutów dziesięć }\end{array}$ & 4. & 5. & 10. \\
\hline Ampułek wewnątrz wyzłacanych próby szóstej dwie, ważą łutów pięć & 2. & - & 5. \\
\hline$V^{\text {Vasculaaa }}$ do śś. olejów szóstej próby trzy, ważą łutów sześć & 3. & & 6. \\
\hline $\begin{array}{l}\text { Vasculum do chorych wewnątrz wyzłacane, trzynastej próby jedno, waży } \\
\text { łutów cztery }\end{array}$ & 1. & & 4. \\
\hline $\begin{array}{l}\text { [s. 11] Koron u obrazu Matki Boskiej w części pozłacanych próby } \\
\text { dziesiątej trzy, wszystkie ważą łutów piętnaście }\end{array}$ & 3. & - & 15. \\
\hline $\begin{array}{l}\text { Szata Matki Boskiej (na niej zawieszony gryf miedziany, dwa kanon- } \\
\text { ickie dystynktoria ze sznurkiem pozłacanym order Ś. Włodzimierza } \\
\text { szpilka z główką z kamuszków szkockich i trzy sznurki różnych koralów } \\
\text { (w części pozłacane, dziesiątej próby jedna, waży funtów trzy, łutów } \\
\text { cztery }\end{array}$ & 1. & 3. & 4. \\
\hline $\begin{array}{l}\text { Gwiazdeczek w koronie Zbawiciela dziesiątej próby siedm, wszystkie } \\
\text { ważą łutów trzy i pół }\end{array}$ & 7. & - & $3^{\prime \prime}$ \\
\hline \multicolumn{4}{|l|}{ Miedź } \\
\hline $\begin{array}{l}\text { Kociołek do chrztu w figurze wazona nowo pobielany z nakrywką jeden, } \\
\text { waży funtów sześć }\end{array}$ & 1. & 6. & - \\
\hline Wotów na obrazie Zbawiciela posrebrzanych dwa, ważą łutów pięć & 2. & - & 5. \\
\hline Łyżka do odlewania świec jedna, waży funt jeden & 1. & 1. & - \\
\hline \multicolumn{4}{|l|}{ Mosiądz } \\
\hline Lichtarzów na wielkim ołtarzu ośm, ważą funtów dwadzieścia cztery & 8. & 24. & - \\
\hline Kociołek do aspersyi jeden, waży funtów sześć & 1. & 6. & - \\
\hline $\begin{array}{l}\text { Miednica przy drzwiach wielkich do wody święconej pobielana jedna, } \\
\text { waży funtów trzy }\end{array}$ & 1. & 3. & - \\
\hline Turybularzów nowo pobielanych dwa, ważą funtów cztery & 2. & 4. & \\
\hline Łódka do kadzidła z łyżeczką jedna, waży łutów ośm & 1. & - & 8. \\
\hline Lawaterz z kubkiem jeden, waży funtów trzy & 1. & 3. & - \\
\hline $\begin{array}{l}\text { Kulek na gzemsach ołtarzowych Matki Boskiej i Ś. Michała cztery, } \\
\text { wszystkie ważą funtów dziewięć }\end{array}$ & 4. & 9. & - \\
\hline
\end{tabular}




\begin{tabular}{|c|c|c|c|}
\hline Kropielniczek dwie, ważą łutów pięć & 2. & - & 5. \\
\hline Passyjek cztery & 4. & - & - \\
\hline Krzyż w ścianie przy chrzcielnicy jeden & 1. & - & - \\
\hline Krzyż ręczny w zakrystyi pobielany jeden, waży funtów dwa & 1. & 2. & - \\
\hline [s. 12] Łopatek do śś. olejów trzy, ważą łutów pięć & 3. & - & 5. \\
\hline Pieczęć kościelna jedna & 1. & & \\
\hline \multicolumn{4}{|l|}{ Cyna } \\
\hline $\begin{array}{l}\text { Lichtarzów wielkich na ołtarzu wielkim sześć, ważą funtów } \\
\text { czterdzieści }\end{array}$ & 6. & 40. & - \\
\hline $\begin{array}{l}\text { Lichtarzów mniejszych na bocznych ołtarzach szesnaście, ważą funtów } \\
\text { czterdzieści dziewięć }\end{array}$ & 16. & 49. & - \\
\hline Lamp wiszących dwie, ważą funtów dziesięć & 2. & 10. & - \\
\hline Krzyż na wielkim ołtarzu jeden, waży funtów ośm & 1. & 8. & - \\
\hline \multicolumn{4}{|l|}{ Spiż } \\
\hline Dzwonów w dzwonnicy cztery, ważą funtów dwa tysiące & 4. & 2000 & - \\
\hline Sygnaturka w kopule jedna, waży funtów trzynaście & 1. & 13. & - \\
\hline Dzwonek przy zakrystyi jeden, waży funtów trzy & 1. & 3. & \\
\hline Dzwonków przy ołtarzach sześć, wszystkie ważą funtów cztery & 6. & 4. & \\
\hline \multicolumn{4}{|l|}{ Żelazo } \\
\hline Żelazka do pieczenia opłatków dwa & 2. & - & - \\
\hline Cyrkuł ${ }^{\mathrm{cc}}$ do robienia komunikantów jeden & 1. & - & - \\
\hline Szczypce do ucinania świec jedne & 1. & - & - \\
\hline Nożyczki do ostrzygania hostyi jedne & 1. & - & - \\
\hline Lichtarzyków małych w esy ośm & 8. & - & - \\
\hline Lichtarzyków szkłem ozdobionych cztery & 4. & - & - \\
\hline Krzyż czuhunny dd na ołtarzu Ś. Michała jeden, waży funtów pięć & 1. & 5. & - \\
\hline
\end{tabular}

aa Vasculum (łac. małe naczynie; 1.mn. vascula) - nieduże naczynie liturgiczne z wodą, zazwyczaj stojące przy tabernakulum, służące do obmycia palców przez szafarza po udzieleniu Komunii Świętej.

${ }^{\text {bb }}$ Order św. Włodzimierza - odznaczenie za zasługi cywilne i wojskowe w Rosji carskiej. Został ustanowiony dnia 22 IX 1782 roku przez carycę Katarzynę II z okazji 20 jubileuszu jej panowania. Order był poświęcony św. Włodzimierzowi Wielkiemu (962/964 - 1015), synowi Świętosława, księciu kijowskiemu, który podporządkował sobie wiele plemion ruskich, Bułgarów kamskich i Chazarów. Zawiązał korzystny dla Rusi sojusz z Bizancjum i przyjął chrzest w 988 oraz wprowadził na Rusi Kijowskiej chrześcijaństwo.

${ }^{c c}$ Cyrkuł - narzędzie do robienia komunikantów.

dd Czuhunny (regionalne z ros. tugun żeliwo, odlewniczy stop żelaza) - żelazny, żeliwny. 


\section{Księgi kościelne obrządkowe i inne:}

\begin{tabular}{|c|c|}
\hline & Tomy i egzemplarze \\
\hline Mszałów światłych trzy & 3. \\
\hline Mszalików żałobnych dwa & 2. \\
\hline Ajend większa i mniejsza dwie & 2. \\
\hline Kancjonalik $^{\mathrm{ee}}$ pisany jeden & 1. \\
\hline Brewiarz stary jeden & 1. \\
\hline Księga bractwa Ś. Trójcy jedna & 1. \\
\hline [s. 13] Biblia łacińska ${ }^{\text {ff }}$ jedna & 1. \\
\hline Komentarz na Ewangelie Natalisa Alexandragg, tom jeden & 1. \\
\hline Komentarz na Ewangelie Augustyna ${ }^{\text {hh }}$, tomów dwa & 2. \\
\hline Komentarz na Ewangelie Oryginesa ${ }^{\text {ii }}$, tom jeden & 1. \\
\hline Homilie Chryzostoma $\mathrm{a}^{\mathrm{j} j}$, tom jeden & 1. \\
\hline Teologia Tamburyniego ${ }^{\mathrm{kk}}$, tom jeden & 1. \\
\hline Teologia Lacrois ${ }^{11}$, tomów dwa & 2. \\
\hline Homilie Białobrzeskiego ${ }^{\mathrm{mm}}$, tomów cztery & 4. \\
\hline Kazania Fabryjusza $^{\text {nn }}$, tom jeden & 1. \\
\hline Prawo Kanoniczne Barbozy ${ }^{\circ 0}$, tom jeden & 1. \\
\hline Historia kościelna Euzebiusza Pamfila ${ }^{\mathrm{p}}$, tom jeden & 1. \\
\hline Mundus symbolicus ${ }^{\mathrm{rr}}$, tom jeden & 1. \\
\hline Hermeneutyka Jansensa ${ }^{\text {ss }}$ tomów dwa & 2. \\
\hline Słownik łacińsko-polski Knapskiego ${ }^{\text {tt }}$ egzemplarz jeden & 1. \\
\hline Ewangeliczka jedna & 1. \\
\hline
\end{tabular}

${ }^{\text {ee }}$ Kancjonał - zbiór popularnych kościelnych pieśni religijnych lub śpiewów liturgicznych kantyk i kantyczek.

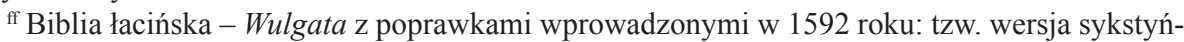
sko-klementyńska. Oficjalna wersja Biblii Kościoła rzymskiego.

gg Aleksander Natalis (1639-1724) dominikanin pochodzenia francuskiego, doktor teologii, zajmował się pracą kaznodziejską i nauką. Sprzyjał jansenizmowi w kwestii łaski i rygoryzmu. Z czasem stał się jego zdecydowanym krytykiem. Tu mowa o jego dziele: Expositio literalis et moralis SS. Evangeliorum secundum quatuor Evangelistas, Paris 1703. M. Nowodworski, Encyklopedia Kościelna, t. 15, Warszawa 1883, s. 583-585.

hh Augustyn, Aurelius Augustinus (354-430), święty, biskup, filozof i teolog, ojciec i doktor Kościoła, czołowy przedstawiciel patrystyki, główny autorytet filozofii i teologii chrześcijańskiej. W latach 413-418 napisał komentarz do Ewangelii w 124 homiliach: In Iohannis Evangelium tractatus centum viginti quatuor. Fragmenty w przekładzie na język polski wydał A. Bober, Antologia patrystyczna, Kraków 1966.

ii Orygines, właściwie: Orygenes (ok. 185-254), pisarz chrześc., egzegeta i tłumacz. Był autorem wielu pism teol. (m.in. komentarza do Ewangelii wg św. Jana) i synoptycznego zestawienia sześciu przekładów Pisma Świętego.

jj Jan Chryzostom, Jan Złotousty (ok. 350-407), Ojciec Kościoła, wywarł wielki wpływ na egzegezę Pisma Świętego swoimi objaśnieniami do całego Starego i Nowego Testamentu. Wykład Nowego Testamentu jest o wiele obszerniejszy niż Starego Testamentu. Obejmuje 88 homilii o Ewangelii św. Jana, 33 homilie wyjaśniające List do Rzymian, 11 homilii - 1 List do Koryntian, 30 homilii - 2 List do Koryntian, 24 homilie - List do Efezjan, 15 homilii - List do Filipian, 12 homilii - List do Kolosan, 11 homilii - List do Tymoteusza, 6 homilii - List do Tytusa, 34 homilie - List do Hebrajczyków, 65 homilii - Dzieje Apostolskie. Egzegetyczny charakter mają homilie do 
psalmów (Expositiones in Psalmos 3-12, 41-49, 108-150), a także m.in. homilii O posagach do ludu Antiochii (De Statuis ad populum Antiochiae), por. M. Nowodworski, Encyklopedia Kościelna, t. 3, Warszawa 1874, s. 350-356.

kk Tamburini Tomasso (1591-1675), jezuita włoski, wykładał teologię dogmatyczną i moralną. Słynął z wielkiej świątobliwości i daru nauczania. Jest autorem dzieł z dziedziny teologii moralnej (o przykazaniach, spowiedzi, Komunii Świętej, Mszy Świętej), które doczekały się powtórnych wydań. Por. M. Nowodworski, Encyklopedia Kościelna, t. 28, Warszawa 1905, s. 179.

${ }^{11}$ Lacroix Claude (1652-1714), jezuita, teolog, moralista. Jego najważniejsze dzieło, które przyniosło mu sławę jednego z najlepszych moralistów swego okresu, była Theologia moralis, t. I-VIII, Köln 1707-1714. W ciągu następnych 50 lat ukazało się 25 poprawionych i uzupełnionych wydań. Por. R. Dziura, Lacroix Claude, EK, t. 10, Lublin 2004, k. 355-356.

mm Białobrzeski Marcin (ok. 1530-1586) cysters, teolog, kaznodzieja. Był opatem w Mogile, biskupem sufraganem krakowskim, delegatem na sejm konwokacyjny i elekcyjny w Warszawie w 1573 roku. W 1577 roku otrzymał biskupstwo w Kamieńcu Podolskim. Pozostawał pod wpływem idei Erazma z Rotterdamu. Napisał: Wykład świętych ewangelii niedzielnych i świąt uroczystych, t. I-IV, Włocławek 1838-1847. Twórczość kaznodziejska Białobrzeskiego jest oparta na Piśmie Świętym i Ojcach Kościoła. Por. M. Brzozowski, Białobrzeski Marcin SOCist, EK, t. 2, Lublin 1995, k. 365-366.

${ }^{n n}$ Faber Stapulensis Jacobus (właściwie Jacques Lefčvre d’Étaples, ur. ok. 1455-1536), francuski humanista, filozof i teolog. Dokonał pierwszego kompletnego przekładu Biblii na język francuski. Wśród jego dzieł teologicznych są m.in. De Maria Magdalena, triduo Christi et ex tribus una Maria disceptatio, Paris 1517; Commentarii initiatorii in quatuor Evangelia, Basel 1523; Commentarii in Epistolas catholicas, Basel 1527. Por. S. Kamiński, Faber Stapulensis, w: Encyklopedia Filozofii, t. 3, Lublin 2002, s. 356-357.

${ }^{\circ o}$ Barbosa Agostino (1590-1649), prawnik, kanonista, od 1648 roku biskup Otrantu. Napisał m.in.: Iuris ecclesiastici universi, t. I-III, Lyon 1633-1634. Jego dzieła miały liczne wydania we Francji, Włoszech, Hiszpanii i Niderlandach. Od 1716 roku ukazało się 16 tomów in folio jego Opera omnia. Por. J. Grzywacz, Barbosa Agostino, EK, t. 2 Lublin 1995, k. 24; M. Nowodworski, Encyklopedia Kościelna, t. 2, Warszawa 1873, s. 5.

${ }^{\mathrm{pp}}$ Euzebiusz z Cezarei (ur. ok. 264-340), pisarz, teolog, zwany ojcem historii Kościoła, biskup Cezarei w Palestynie od 313 roku. Uczeń Pamfila z Cezarei, obrońcy twórczości Orygenesa, jako wyraz oddania dla swego mistrza, przyjął przydomek „syn Pamfila”. Jest autorem historii Kościoła: Ekklesiastike historia $\mathrm{w} 10$ księgach. Jest ona pierwszą próbą przedstawienia dziejów Kościoła od jego założenia do czasów zwycięstwa Konstantyna Wielkiego nad Licyniuszem w 324 roku. Por. F. Drączkowski, Euzebiusz z Cezarei, EK, t. 4 Lublin 1985, k. 1351-1355.

זr Picinelli Filippo (1604-1678), włoski opat i uczony, autor dzieła Mundus symbolicus, in emblematum universitate formatus, explicatus, et tam sacris, quam profanis eruditionibus ac sententiis illustratus [...], t. 1-2, Coloniae Agrippinae 1687.

ss Hermeneutyka - chodzi tu prawdopodobnie o dzieło Corneliusa Jansena Starszego (15101576) biskupa Gandawy, biblisty, profesora egzegezy na uniwersytecie w Lowanium, autora komentarzy biblijnych. Por. S. J. Kosa, Jansen Cornelius Starszy, EK, t. 7 Lublin 1997, k. 988-989.

"Grzegorz Knapiusz, Cnapius, Knapski (ok. 1564-1639), jezuita, filolog, pisarz, poeta, filozof, nauczyciel kolegiów jezuickich. Jego głównym dziełem jest słownik polsko-łacińsko-grecki: Thesaurus Polono-Latino-Graecus (tom I-III, wydany w Krakowie 1621, 1632). Wydany w 1643 r. poszerzony tom I, uznawany był za najlepszą publikację tego rodzaju w Polsce przedrozbiorowej, stanowił także podstawę podobnych słowników litewskich, łotewskich i rosyjskich. Oprócz polskołacińskiego materiału leksykalnego (tomy I-II) słownik Knapiusza zawiera zbiór polskich przysłów i sentencji (tom III - Adagia Polonica). Por. R. Sawa, Knapiusz Grzegorz SJ, EK, t. 9 Lublin 2002, k. 199. 
Księgi metryczne:

\begin{tabular}{|c|c|c|}
\hline & & egzemplarze \\
\hline \multirow{4}{*}{ Księgi metryk chrzestnych } & $\begin{array}{l}\text { 1) Od r. } 1679, \text { d. } 24 \text { sierp[nia], do r. } 1784 \text {, d. } 24 \\
\text { marca }\end{array}$ & 1. \\
\hline & $\begin{array}{l}\text { 2) Od r. } 1787 \text {, d. } 13 \text { stycznia do r. } 1800 \text {, d. } 11 \\
\text { grudnia }\end{array}$ & 1. \\
\hline & $\begin{array}{l}\text { 3) Od r. } 1801 \text {, d. } 1 \text { stycznia do r. } 1826 \text {, d. } 24 \\
\text { marca }\end{array}$ & 1. \\
\hline & 4) Od r. 1827 , d. 27 stycznia w kontynuowaniu & 1. \\
\hline \multirow{4}{*}{ Księgi metryk ślubnych } & $\begin{array}{l}\text { 1) Od r. } 1671 \text {, d. } 20 \text { grudnia do r. } 1783 \text {, d. } 14 \\
\text { listopada }\end{array}$ & 1. \\
\hline & $\begin{array}{l}\text { 2) Od r. 1784, d.10 października do r. 1800, d. } 11 \\
\text { listopada }\end{array}$ & 1. \\
\hline & $\begin{array}{l}\text { 3) Od r. } 1801 \text {, d. } 23 \text { stycznia do r. } 1826 \text {, d. } 10 \\
\text { czerwca }\end{array}$ & 1. \\
\hline & 4) Od r. 1827 , d. 25 września w kontynuacji & 1. \\
\hline \multirow{4}{*}{$\begin{array}{l}\text { Księgi metryk } \\
\text { pogrzebowych }\end{array}$} & $\begin{array}{l}\text { 1) Od r. } 1721 \text {, d. } 27 \text { kwietnia do r. } 1784 \text {, d. } 8 . \\
\text { Kwietnia }\end{array}$ & 1. \\
\hline & $\begin{array}{l}\text { 2) Od r. } 1785 \text {, d. } 12 . \text { marca do r. } 1800, \text { d. } 28 \\
\text { grudnia }\end{array}$ & 1. \\
\hline & $\begin{array}{l}\text { 3) Od r. 1801. d. 5. stycznia do r. } 1826 \text { d. } 31 . \\
\text { grudnia }\end{array}$ & 1. \\
\hline & 4) Od r. 1827 d. 19. stycznia w kontynuacyi & 1 \\
\hline $\begin{array}{l}\text { Księga egzaminów } \\
\text { przedślubnych }\end{array}$ & Od r. 1827. d. 25. września w kontynuacyi & 1. \\
\hline Status animarum & Od 1822 r. i od 1828 r. do teraźniejszej daty & 1. \\
\hline
\end{tabular}

Zewnątrz kościoła plac, cmentarzem nazwany, w kwadrat sztachetami ogrodzony, do którego brama także podwójna z takiemiż [s. 14] z obu stron furtkami. Takaż furtka prowadząca na uliczkę do plebanii. Na cmentarzu z lewej od bramy strony dzwonnica drewniana dwupiętrowa w kwadrat w figurze wieży zbudowana, tarcicami opierzona, $\mathrm{z}$ dachem gontowym, na którym krzyż żelazny w promieniach. W niej są cztery dzwony: których waga wyżej opisana. Oprócz dzwonnicy wymurowane są dwa nagrobki familii Roszkowskich i Zieńkiewiczowej.

Dywiński kościół graniczy z parafialnemi kościołami: od północy z kobryńskim i horodeckim; od 1-go odległy na wiorst 34, a od 2-go letnią porą na wiorst 37 , zimą zaś, gdy błota zamarzną, na wiorst 21 . Od wschodu z rateńskim wołyńskiej guberni, odległym na wiorst 35 . Od południa i zachodu z krupczyckim, odległym na wiorst 35 . Od miasta guberńskiego Grodna odległy na wiorst 230 . Od powiatowego Kobrynia na wiorst 34.

Plebanem tego Kościoła jest ksiądz Piotr Kamińskii ${ }^{23}$ magister teologii od roku 1844. Duchowne nauki skończył w byłym Uniwersytecie Wileńskim. Wikariusza nie ma.

${ }^{23}$ Ks. Piotr Kamiński studia teologiczne ukończył w byłym Uniwersytecie Wileńskim, magister teologii od 1844 roku, proboszcz parafii Dywin. 
Słudzy kościelni. Organista Jan Tynkiewicz wolno skazkowy ${ }^{24}$, wyznania rzymsko-katolickiego. Zakrystiana i dziadów do dzwonnicy nie ma. W potrzebie do posług kościelnych i do dzwonienia najmuje pleban ludzi miejscowych miasteczka Dywina.

W dywińskiej parafii liczy się parafian płci męskiej i żeńskiej w ogóle do pięciuset, podług rejestru corocznie w tym celu spisującego się. Filialnych i przyłączonych Kościołów nie ma. Księgi metryczne zaprowadzone od r. 1671, które porządnie i bezpiecznie są utrzymane. Tudzież księgi dla zapisywania rozporządzeń wyższej zwierzchności i rządu znajdują się na należytym stanie.

\section{Opisanie funduszowych zabudowań}

Od rynku z prawej strony brama podwójna z sztachet nowa na zawiasach i krukach żelaznych, z takąż obok furtką.

[s. 15] Dalej też po prawej ręce dom mieszkalny plebański stary, z drzewa ciosanego w węgieł gładki, podług miejscowej ustnej tradycyi około roku 1800 zbudowany. Dach słomą nowo pokryty z trzema nad nim wyprowadzonemi kominami. Ma długości 24, szerokości 14 arszynów. Przy wejściu ganek o czterech słupach, z bokami częścią z desek częścią z sztachet. Z niego drzwi do sieni ciesielskiej roboty na zawiasach i krukach żelaznych z zamkiem wnętrznym. Z sieni po lewej ręce drzwi do pokoju taflowe, nowe, stolarskiej roboty, na zawiasach i krukach żelaznych z zamkiem wnętrznym. Z prawej strony pokoju nowy ceglany kominek z szafeczką, do której drzwiczki taflowe stolarskiej roboty podwójne $\mathrm{z}$ zameczkiem wnętrznym. Kominek ten połączony z nowym długim w miejscu ściany ceglanym piecem. Okien w tym pokoju nowych w drzewo oprawnych z częścią szybami okutych trzy. $Z$ tego pokoju drzwi podwójne do pokoju drugiego, nowe, stolarskiej roboty na zawiasach i krukach żelaznych, z zamkiem wnętrznym. W nim jedno takież jak i w pierwszym pokoju okno. W końcu garderóbka z nowymi, taflowemi ${ }^{25}$, stolarskiej roboty, na zawiasach i krukach żelaznych drzwiami. Z tego pokoju drzwi podwójne stolarskiej roboty na zawiasach i krukach żelaznych z zamkiem wnętrznym do pokoiku sypialnego. W nim ceglany piec szwedzki i jedno w drzewo oprawne o czterech szybach okno. Wszystkie drzwi i okna z lamperiami blejwasowo ${ }^{26}$ na pokost malowane. Okna zewnątrz okiennicami nowymi taflowemi podwójnemi stolarskiej roboty, podobnież malowanemi i okutymi, żelaznym prętem wewnątrz zamykającymi się są opatrzone. $\mathrm{Z}$ prawej sieni strony drzwi nowe taflowe stolarskiej roboty na zawiasach i krukach żelaznych z zamkiem wnętrznym do pokoju drugiej domu połowy. Po lewej ręce tego pokoju ceglany kominek, obok którego nowy ceglany szwedzki piec, wszystkie pokoje tej połowy ogrzewający. W pierwszym pokoju trzy okna w drzewo oprawne i okute, o sześciu szybach. Z niego drzwi podwójne stolarskiej roboty na zawiasach i krukach żelaznych z zamkiem wnętrznym do pokoju drugiego:

${ }^{24}$ Wolno skazkowy (z ros. сказковый) zgodny z rejestrem, tu: stanu wolnego.

${ }^{25}$ Tafla - płyta ze sztywnego, gładkiego materiału, zwykle prostokątna. Drzwi taflowe - mające kształt tafli, będące taflą, wykonane $\mathrm{z}$ tafli.

${ }^{26}$ Blejwasowo ... malowane - bielą ołowiową, bielidłem (od niem. Bleiweiss biel ołowiowa). 
W nim takichże jak w pierwszym pokoju okien dwa. W końcu podobneż drzwi z zaszczepką żelazną do pokoju trzeciego: [s. 16] w którym okno takież jak i powyższe jedno. $Z$ niego drzwi stolarskiej roboty na zawiasach i krukach żelaznych z zamkiem wnętrznym do sionek: skąd drzwi ciesielskiej roboty na zawiasach i krukach żelaznych z zasuwką na podwórze. We wszystkich tego domu pokojach, jak również w sieniach i ganku podłoga i stolowanie z tarcic. Ściany wszystkich pokojów wewnątrz nowo są tynkowane i pobielone.

Naprzeciw mieszkalnego domu w niewielkiej odległości dom czeladni drewniany, zbudowany podług miejscowego podania około roku 1818, z dachem z dranic i z kominem nad nim wyprowadzonym. Ma długości 24, szerokości 16. arszynów. Na wejściu drzwi do sieni ciesielskiej roboty na zawiasach i krukach żelaznych z klamką i zasuwką. W sieniach murowana z cegieł kuchnia z takiemiż drzwiami. Po lewej ręce takież drzwi do izby czeladniej. W niej okien w drzewo oprawnych szkła drobnego wielkich trzy i jedno małe. Podłoga i stolowanie z tarcic. Ściany nowo tynkowane. Piec z cegły nowy, fizyczny, z kapturem, w końcu z ceglanym kominem. Od niego drzwi takież jak i pierwsze do komory: w której okno w drzewo oprawne, szkła drobnego, wielkie, jedno. Posadzka z gliny, stolowanie $\mathrm{z}$ tarcic. Z komory drzwi takież do spiżarni: w której posadzka naturalna, stolowanie $\mathrm{z}$ tarcic. $Z$ prawej strony sieni drzwi nowe stolarskiej roboty na zawiasach i krukach żelaznych z klamką do stancyi drugiej połowy domu: w której okien nowych w drzewo oprawnych o sześciu szybach z lamperiami, trzy. Piec z cegły nowy, fizyczny, z kapturem. Z tej stancyi drzwi taflowe stolarskiej roboty na zawiasach i krukach żelaznych z klamką do alkierza, w którym przy drzwiach kominek złączony z opisanym piecem. Okno jedno, takież, jak i powyższe. W obu tych stancjach podłoga i stolowanie z tarcic nowe. Ściany nowo tynkowane i pobielane. W końcu tej połowy domu z podwórza drzwi ciesielskiej roboty na zawiasach i krukach żelaznych do sionek: z których drzwi takież z zamkiem wnętrznym i klamką do pokoiku. [s. 17] W nim piec z cegły nowy, fizyczny, z kapturem. Okno w drzewo oprawne, o sześciu szybach, okute, jedno. Po prawej ręce drzwi takież z żelazną zaszczepką do garderóbki: gdzie okienko o dwóch podłużnych szybach, małe jedno. $Z$ pierwszego pokoiku drzwi podobneż do pokoiku drugiego: w którym okno takież jak i w pierwszym z okiennicą zewnętrzną, okutą jedno. Kominek z cegły z piecem złączony. W obu tych pokoikach ściany boczne nowo tynkowane. Podłoga i stolowanie z tarcic. Oba tu opisane domy we wszystkich szczegółach wewnątrz wygodnie i gustownie zrestaurowane przez teraźniejszego plebana kiędza Piotra Kamińskiego.

O kilka kroków od domu czeladniego studnia z nowym z tarcic dębowych zrębem, nowo wokoło dylami sosnowemi ocembrowana z żurawiem. Po prawej ręce od domu czeladniego chlew dla świń drewniany $\mathrm{z}$ dachem słomianym, z czterma na biegunach ${ }^{27}$ pojedynczemi drzwiami i z kilką wewnątrz przegroda-

${ }^{27}$ Bieguny - w starych budowlach rodzaj zawiasów u drzwi i wrót. Były to drewniane pionowe czopy wystające z obrysu drzwi. Czopy obracały się w otworach zwanych stępkami. Pierwotnie wszystkie drzwi we dworach i chałupach wiejskich obracały się na biegunach drewnianych. Z biegiem lat, w miarę upowszechniania się wyrobów stalowych, miejsce biegunów drewnianych zajęły bieguny stalowe, a następnie zawiasy stalowe. 
mi. Z lewej tegoż domu strony spichrz drewniany, dranicami kryty, z frontu z gankiem o czterech drewnianych słupach, $\mathrm{z}$ drzwiami pojedynczemi ciesielskiej roboty na zawiasach i krukach żelaznych z zamkiem wnętrznym. W nim podłoga i stolowanie $\mathrm{z}$ tarcic, bez zasieków. W równej linii z lewej strony syrnica ${ }^{28} \mathrm{w}$ kwadrat z kołków na grubym drewnianym słupie wzniesiona, z dachem nowym dranicznym i drewnianemi wschodami. $W$ tejże linii spichrz drugi drewniany $z$ dwiema stronami, dranicami pokryty. Do obu stron drzwi ciesielskiej roboty na zawiasach i krukach żelaznych, z zamkami wnętrznymi. Pierwsza strona z trzema zasiekami, a druga $z$ jednym. W obu podłoga i stolowanie $z$ tarcic. $Z$ prawej strony domu mieszkalnego stajnia drewniana $\mathrm{z}$ dachem słomianym, $\mathrm{z}$ dwiema udzielnemi stronami. Do obu drzwi pojedyncze z desek na biegunach. Ze stajnią połączona obora drewniana $\mathrm{w}$ figurze kwadratu, $\mathrm{z}$ dachem słomianym. Zewnątrz drzwi pojedynczych z desek na biegunach dwoje. Wewnątrz z takiemiż drzwiami trzy przedziały, z małemi po końcach przegródkami dla cieląt. Obok stajni wozownia drewniana słomą pokryta. W niej drzwi pojedyncze na biegunach, podłoga [s. 18] i stolowanie z tarcic. Za wozownią gumno, czyli stodoła na skład zboża, z drzewa słomą pokryta, stara, z pięcią pojedynczymi z desek na biegunach drzwiami. Przy stodole szopa na siano drewniana, słomą pokryta: do niej drzwi pojedynczych z desek na biegunach z obu stron dwoje. Za domem mieszkalnym loch w ziemi z drzewa zbudowany, $\mathrm{z}$ dachem słomianym nowym, z podwójnymi u wejścia ciesielskiej roboty, drzwiami na zawiasach i krukach żelaznych, z zamkiem wiszącym, i z dwóma wewnątrz przedziałami: do których drzwi na zawiasach i krukach żelaznych do zamków wiszących. Za kościołem lodownia ${ }^{29} \mathrm{z}$ dylow ${ }^{30}$ dębowych w ziemi zbudowana $z$ dachem słomianym: do niej drzwi ciesielskiej roboty na zawiasach i krukach żelaznych z zamkiem wnętrznym. Wewnątrz drzwi takież leżące do środka lodowni schodami drewnianemi $\mathrm{w}$ dół prowadzące. $\mathrm{Z}$ trzech stron są skrzynie dla składu lodu, tarcicami służącymi za podłogę opatrzone.

Ogrodzenie dziedzińca i ogrodu już z parkanu, już z kołów dębowych i sosnowych łozą przeplatanych, w większej części nowe.

Po lewej ręce od frontu kościoła przy ulicy Rateńskiej dom dla organisty drewniany, stary, $z$ dachem słomianym i z kominem nad nim wyprowadzonym. Przy wejściu drzwi na biegunach z klamką do sieni: z tych po lewej ręce drzwi na zawiasach i krukach żelaznych do stancyi: w której okien dwa i piec fizyczny. Naprzeciwko komora z takiemiż drzwiami. Przy końcu przybudowany zewnątrz mały chlewuszek dla świń i drobiu. Ogródek niewielki.

Wszystkie wyżej opisane budowle przez śp. księdza Jana Piaskowskiego ${ }^{31}$, plebana dywińskiego różnoczasowe są pobudowane, a stare przesypane, i wszystkie, oprócz gumna, w dobrym stanie.

${ }^{28}$ Syrnica - lekkie, drewniane zabudowanie gospodarcze (szopa), ze względu na podmokły teren stawiana była na słupach drewnianych nad ziemią.

${ }^{29}$ Lodownia - rodzaj piwnicy do przetrzymywania produktów w stałej i chłodnej temperaturze.

${ }^{30}$ Dyl - pień drzewny, bal, belka. W budownictwie - gruba deska używana w drewnianych konstrukcjach stropowych ściennych, mostowych itp.

${ }^{31}$ Ks. Jan Piankowski, proboszcz w Dywinie w latach 1796-1830. 
[s. 19] Ilość ziemi przez komisją delegowaną od Izby Grodzieńskiej Dóbr Państwa w roku 1842 na fundusz wydzielonej.

\begin{tabular}{|c|c|c|}
\hline & $\begin{array}{l}\text { Dziesięci- } \\
\text { ny }\end{array}$ & Sznury \\
\hline $\begin{array}{l}\text { Ziemia orna składa się z czterech udzielnych uroczysk, a mianowicie } \\
\text { Rynkowego pod Kościołem, probostwem i ogrodami dziesięcin cztery, } \\
\text { prętów }{ }^{\text {uu }} \text { tysiąc trzysta czterdzieści cztery }\end{array}$ & 4. & 1344. \\
\hline $\begin{array}{l}\text { Stanowiszcz: dziesięcin siedem, prętów tysiąc ośmset dwadzieście } \\
\text { cztery }\end{array}$ & 7. & 1824. \\
\hline Łuki: dziesięcin pięć, prętów tysiąc sześćset & 5. & 1600. \\
\hline Łazow: dziesięcin pięć, prętów sześćset dwa i dwie trzecich & 5. & $602 \frac{2}{3}$ \\
\hline \multicolumn{3}{|l|}{ Sianożęci $^{\mathrm{ww}}$} \\
\hline $\begin{array}{l}\text { W uroczysku Stanowiszczach łąki grądowej dziesięcin trzy prętów } \\
\text { ośmset siedemdziesiąt cztery i dwie trzecich }\end{array}$ & 3. & $874^{2} / 3$ \\
\hline $\begin{array}{l}\text { W Łazach łąki błotnej po brzegach z grądową } \mathrm{xx} \text { dziesięcin pięć prętów } \\
\text { tysiąc dwadzieścia dziewięć i jedna trzecich }\end{array}$ & 5. & $10291 / 3$ \\
\hline $\begin{array}{l}\text { W ogóle ziemi ornej z sianożęciami dziesięcin trzydzieści dwie, prę- } \\
\text { tów siedemdziesiąt cztery i dwie trzecich }\end{array}$ & 32. & $742 / 3$ \\
\hline
\end{tabular}

Oprócz tu pokazanej ziemi, która jest średniej dobroci, innych placów i zaścianków nie ma.

Taż komisja wypasy dla bydła i koni zapewniła spólne $\mathrm{z}$ b. funduszową plebańską, a teraz skarbową jurysdyką

$\mathrm{Na}$ opisanej ziemi, a mianowicie w uroczyskach Rynkowem i w Łuce posiano na rok następujący 1845 żyta ozimego szanków dziesięć (10). Szank ${ }^{32}$ miara znaczy ćwierć beczki. [s. 20]

\begin{tabular}{|l|c|c|}
\hline \multicolumn{1}{|c|}{ [s. 20] Dochód } & \multicolumn{2}{c|}{ Srebrem } \\
\cline { 2 - 3 } & Ruble & Kopiejki \\
\hline $\begin{array}{l}\text { a) Pensyi rocznej, etatem przeznaczonej, rubli srebrnych dwieście } \\
\text { trzydzieści }\end{array}$ & 230. & - \\
\hline b) Z wydzielonej ziemi rubli srebrnych piędziesiąt & 50. & - \\
\hline $\begin{array}{l}\text { c) Z dobrowolnych ofiar za spełnianie niektórych posług duchownych } \\
\text { parafianom rubli srebrnych dziesięćc }\end{array}$ & 10. & - \\
\hline d) Dziesięcin i annat nie ma & & \\
\hline W ogóle przychodu rocznego rubli srebrnych dwieście dziewięćdziesiąt & 290. & - \\
\hline
\end{tabular}

Uwaga 1. Dochód z wydzielonej ziemi cały prawie obraca się na najęcie robotnika do uprawy roli, zebrania zboża, wymłócenia i zdjęcia siana.

uu Pręt - równowartość 15 stóp. Stopa - dawna jednostka miary nawiązująca do przeciętnej długości stopy ludzkiej. Różniła się wielkością w zależności od czasu i miejsca.

ww Sianożęć - łąka, z której trawę zbierano na siano.

${ }^{x x}$ Grądowy (o glebach) - położony na pochylonych równinach.

${ }^{32}$ Szank, szanek (z niem. Schank) - miara objętości towarów sypkich, zwykle zboża, obejmująca 24 lub 48 garnców. 
Uwaga 2. Kahał dywiński według wydanej w roku 1770. dnia 6 czerwca, znajdujący się w Archiwum Diecezjalnym Wileńskiem submissyi, obowiązany dawać kościołowi dywińskiemu corocznie po dwa pudy łoju na światło; lecz od roku 1842 daniny tej nie dostarcza.

\begin{tabular}{|c|c|c|}
\hline \multirow{2}{*}{ Rozchód } & \multicolumn{2}{|c|}{ Srebrem } \\
\hline & Ruble & Kopiejki \\
\hline $\begin{array}{l}\text { a) Na utrzymanie kościoła, jako to: światło, wino, na opłatę sług } \\
\text { kościelnych, reparacją ornatów, mycie bielizny, i inne mniejsze potrzeby } \\
\text { dotąd ekspensuje się rs. }{ }^{y y} \text { osiemdziesiąt }\end{array}$ & 80. & - \\
\hline $\begin{array}{l}\text { b) Na utrzymanie plebana, mieszkalnego domu i potrzebnej posługi dotąd } \\
\text { wydatkuje się rs. dwieście pięćdziesiąt }\end{array}$ & 250. & - \\
\hline $\begin{array}{l}\text { c) Na utrzymanie koni i pojazdu dla dojeżdżania do chorych i zwizytowania } \\
\text { parafii dotąd ekspensuje }{ }^{z z} \text { się rs. dziewięćdziesiąt }\end{array}$ & 90. & - \\
\hline $\begin{array}{l}\text { d) Na utrzymanie dziekana, procent piąty od naznaczonej pensyi rubli } \\
\text { srebrnych jedenaście, kopiejek pięćdziesiąt }\end{array}$ & 11. & 50 \\
\hline W ogóle rozchodu rocznego rubli $[\ldots]$ dwieście jeden $[\ldots]$ & 201. & - \\
\hline
\end{tabular}

\section{[s. 21] Porządek nabożeństwa:}

a) W dni niedzielne, uroczyste i świąteczne otwiera się kościół z rana o godzinie ósmej. Około godziny dziewiątej śpiewają się przez organistego Godzinki do Matki Boskiej na organach, które przedłużają się przy innych pieśniach do pół jedenastej. W dniach uroczystych w miejscu Godzinek odprawuje się jutrznia. O godzinie jedenastej rozpoczyna się Msza Ś. summa zwana za parafian żywych i umarłych; w czasie której po Credo mówi się do ludu z ambony kazanie lub homilia. Po summie śpiewa się przy wystawieniu Najświętszego Sakramentu supplikacyja; po niej psalm Bóg nasza ucieczka ... lub Przed oczy Twoje Panie... Na koniec modły za Najjaśniejszego Cesarza i cały Najjaśniejszy Dom Jego. Po południu w dniach uroczystych i często niedzielnych, gdy jest zebranie ludu, odprawują się nieszpory.

$\mathrm{W}$ dniach tabelnych ${ }^{33}$ o godzinie jedenastej śpiewa się Msza Ś.; po której dziękczynny hymn Ciebie Boga chwalimy ... za Najjaśniejszego Cesarza i cały Najjaśniejszy Dom Jego.

Oprócz zwyczajnych uroczystości, jako to: Bożego Narodzenia, Wielkiejnocy, Zesłania Ducha Ś. i innych, jest Uroczystość Wniebowzięcia Matki Boskiej; która jako tytuł Kościoła obchodzi się najuroczyściej z wystawieniem Najświętszego Sakramentu.

[s. 22] b) anniwersarzów nie ma. Obligacyj czytanych w myśl zapisów funduszowych w rok dwieście ośm (208). Z tych w każdym tygodniu po dwie we wtor-

${ }^{\text {yy }}$ Rs. - rubli srebrnych.

${ }^{z z}$ Ekspensować (łac. expensare) - dawniej: wydać pieniądze, ponosić koszty, zużywać.

${ }^{33}$ Dni tabelne - dni, w których należało odprawić w parafiach Mszę św. w intencji obchodzących urodziny lub imieniny członków rodziny carskiej. Nazwa pochodzi od tabel w schematyzmach diecezjalnych, w których zapisywano imiona cara i członków jego rodziny z podaniem dat ich urodzin i imienin. 
ki i soboty za duszę Pana Ruszczyca, i po dwie w śrzody i piątki za kolatorów żywych i umarłych, regularnie się dotąd odprawują.

c) szpitala i bractwa nie ma.

Takową wizytę kościoła parafialnego rzymsko-katolickiego dywińskiego w roku 1844 przeze mnie odprawioną i w czterech zgodnych egzemplarzach spisaną, przy wyciśnięciu pieczęci własną ręką podpisałem: kobryński proboszcz ks. Antoni Kisielewski.

\section{THE VISITATION OF THE PARISH CHURCH IN DYWIN FROM 1844}

\section{Summary}

The borderland town of Dywin (now in the Republic of Belarus) in the district of Kobryn had a church dedicated to the Assumption of the Blessed Virgin Mary which was founded in the second half of the seventeenth century. The parish, having the royal patronage, dates back to 1700 . It was included in the Diocese of Lutsk, in 1798 was moved to the Diocese of Vilnius, and after the establishment of the Diocese of Pinsk in 1925, it became the part of this diocese. Since 1945, the town of Dywin has been outside Poland. The visitation of the parish church in Dywin was conducted in 1844 by the Dean of Kobryn Rev. Antoni Kisielewski. 